\title{
THE CENSUS OF THE 1855 LEAVES OF GRASS: A PRELIMINARY REPORT
}

\author{
ED Folsom
}

IN 1955, during the centennial celebration of the first edition of Leaves of Grass, Gay Wilson Allen wrote, "So far as I know, no one has ever counted the number of copies [of the 1855 Leaves] in existence today-someone should catalog them. ..."' Unfortunately, fifty years later, in 2005, when the sesquicentennial celebration began, the same thing could still be said. So, during the sesquicentennial year, I undertook - with the help of my research assistant, Amy Hezel - the first complete census of all copies of the 1855 Leaves. The goal of the census was to gather as much information as possible about the remaining copies of the first edition, to find out just how many copies of the 1855 edition exist, and to catalog the known variations within the edition. How many variations are there among the remaining copies? What do these variations tell us about the book, its author, and the circumstances of its publication?

That census is still ongoing - we have so far located and surveyed 158 copies, and I believe we will eventually locate about 200 of the original 795 copies of the first edition - and I am pleased to announce that the complete findings, continually updated in a searchable database, will now be available on the Walt Whitman Quarterly Review website (www.uiowa.edu/ wwqr). I want here to offer a preliminary report on some of the remarkable findings we have already made, discoveries that are helping us to know Whitman's book, and the circumstances of its production, in ways we never before had guessed possible.

The census emphasizes the importance of the physical book object in understanding Whitman. Our views of Whitman as a poet alter in significant ways when we keep in mind that he was not only a poet but a trained printer; he not only wrote texts, he put them into print, and, beginning with his publication of Leaves of Grass when he was 36 years old, he became a bookmaker, too. Whitman did not just write his book, he made his book. Let's turn, then, to a brief printer's examination of the first edition of Leaves of Grass. Leaves of Grass began, of course, as a self-publication. No publisher was interested in producing what seemed an odd and inelegant group of twelve untitled poems. So Whitman did it himself: he designed the cover, chose the binding, and set some of 
the type. He talked a friend, Andrew Rome, who was a job printer with a tiny shop on Fulton and Cranberry Streets in Brooklyn, into printing the book. Andrew Rome had just lost his brother and business partner, James, who died of consumption about half a year before Andrew began working on Leaves. Whitman's daily presence in the shop while he was working on his book would have been a great comfort to the grieving older brother. Andrew's next younger brother Thomas, then nineteen, helped out. Bibliographies of Whitman's work always list the "Rome Brothers" as the printers of the first Leaves, but it is significant that Whitman's own earliest recorded recollection of the printing specifies that it was Andrew Rome alone who did the printing - "The first Leaves of Grass was printed in 1855 in Brooklyn New York. . . . 800 copies were struck off on a hand press by Andrew Rome, in whose job office the work was all done - the author himself setting some of the type." ${ }^{2}$ Only in 1864, when Andrew's younger brother Tom was in his mid-twenties, did "A. $\mathrm{H}$. Rome \& Brothers" begin appearing on their publications, and only in 1865 did the firm become "Rome Brothers."

Leaves of Grass is very likely the first book Andrew Rome's tiny firm ever published. His press was hardly set up to publish books at all; the next extant book that Rome printed was in 1858 (a pamphlet of the Brooklyn fire marshal's semi-annual report), followed by a short book on fire insurance laws in 1859. Andrew and Tom would publish city and county reports, Unitarian sermons, one novel, and one other book of poems (by one John Lockwood). ${ }^{3}$ Almost all their books were small paperback pamphlets, flimsy publications, most of which have not survived. Rome mainly published legal forms - blank model legal forms for wills, mortgages, deeds, subpoenas, levies on property, summonses and many other legal transactions and procedures. Such printed forms - with the blank spaces to be filled in ink with the names of the parties, dates, and other relevant details-were widely used by lawyers and peace officers and the general public throughout the nineteenth century. Such forms were staples of the printing trade for over three hundred years. These forms, in the pre-typewriter days of the nineteenth century, were printed on large sheets of paper to allow for the easy addition by hand of names, places, dates, and amounts; the forms were in fact about the same size as the pages of the 1855 Leaves of Grass, and the possibility thus arises that at the time Andrew Rome was printing Leaves, he was using the size paper he would normally have used for the legal forms he was printing.

It has long been assumed that Whitman chose the large-sized paper so that his long lines would have room to wander across the page, but it is likely that Whitman simply had to accept this paper as a convenience, since it was what Andrew had in stock and what his press at that time was set up to handle. Whitman's later editions, including the very small 
pages of the 1856 Leaves, indicate that he was not wedded in any way to the large paper size. Whitman would experiment with many paper sizes during his career but he never returned to the large legal sheets of the original Leaves. And, in fact, Whitman left behind a manuscript page (now in the Humanities Research Center at the University of Texas; see Figure 1) on which he gives printing instructions to Andrew Rome, noting that he has "left five pages with Andrew," and where he lists his twelve poems in a very different order from that which they appear in the 1855 edition and works out some arithmetical estimates of how many words per page his book will have and how many pages it will contain. His calculations end up wildly off the mark.

If we follow Whitman's arithmetic, we can see that he tallies 127 pages of manuscript (although his individual page counts actually add up to 117 pages - a miscalculation that eventually creates empty space for his last-minute addition of a preface, which is nowhere mentioned on the manuscript page). Using pages from "Shakespeare's poems," Whitman estimates that a printed page will contain 1120 letters (28 lines of 40 letters), compared to 1600 letters of "one of my closely written MS pages" (40 lines of 40 letters). In order to create a printer's cast-off, he multiplies 127 by 1600 for a total of 203,200, which he then divides by 1120 , in order to come up with an estimated count of 181 pages. At this point Whitman is clearly imagining a page approximately half the size of the one eventually used - a page much closer in size to the 1856 edition. When Andrew Rome set those initial five pages, then, Whitman would have discovered that Andrew's press was set for legal printing, and the paper and press were prepared for legal forms. Those forms - again, the staple of the Rome business-were now, to Whitman's surprise, the default page size for the 1855 Leaves.

Suddenly Whitman had a very different job on his hands than he initially thought. Working to save money and economize both on the number of frames and the amount of time, Whitman, after setting "I celebrate myself" (later called "Song of Myself") and coming to the end of the seventh gathering of eight pages, began to realize he would not have the luxury of continuing on with lots of blank space, as he had at the end of "I celebrate myself" and the second poem, "Come closer to me" ("Song for Occupations"), which took up the next eight-page gathering (see Figures 2 and 3). At that point he began to economize and to rearrange the poems to get the most type out of the available space on the page, first by giving up blank half-pages (see Figure 4), and then by giving up his running or repeated title of "Leaves of Grass" at the head of each poem (see Figure 5): the final six poems have no heading and are separated only by a double rule. He moved all the shorter poems to the end, clearly to allow himself most effectively to use his typesetter's sense to squeeze them all into twelve eight-page signatures. The arrangement of 


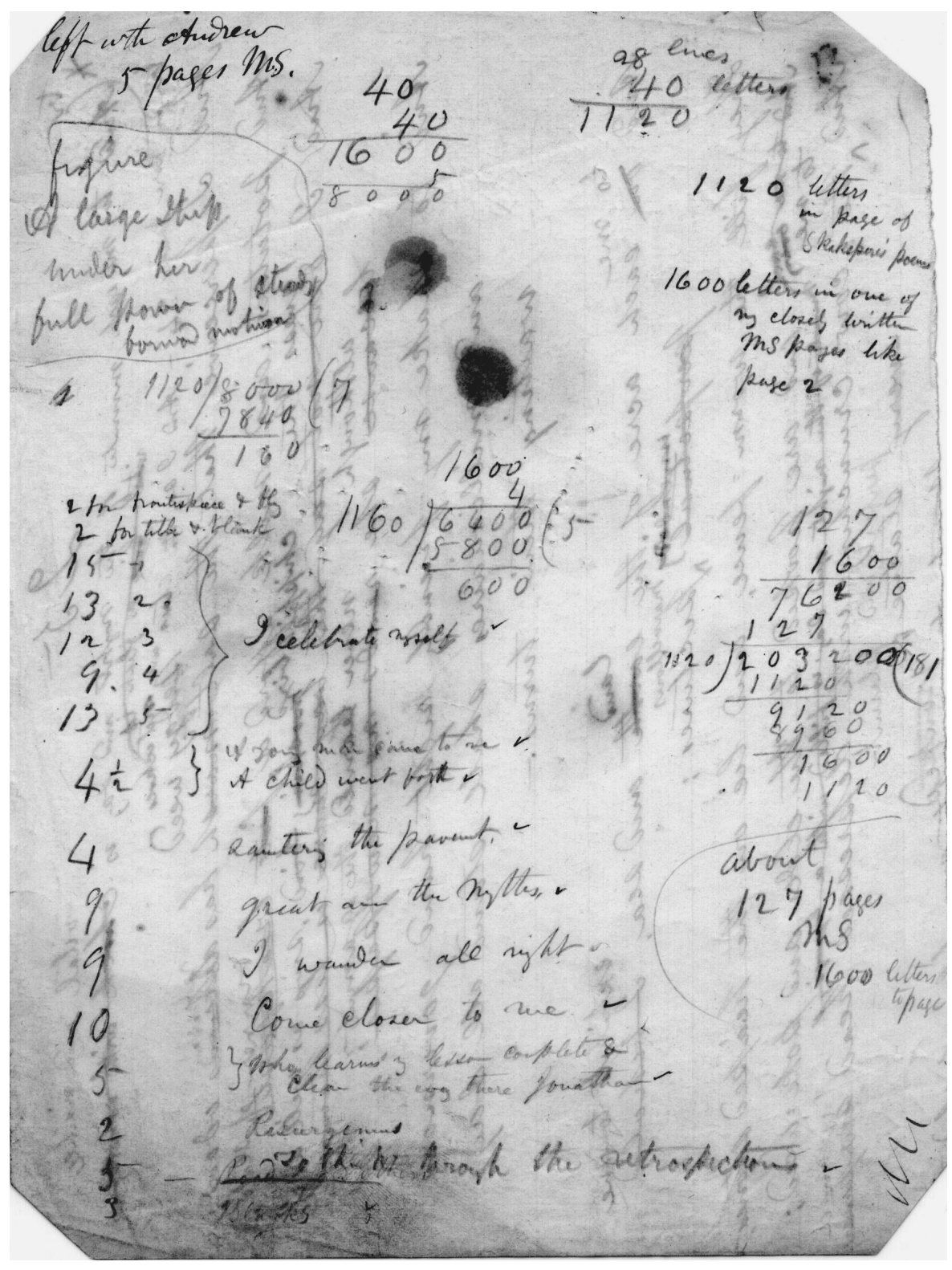

Figure 1. Whitman's Notes for the First edition, Harry Ransom Humanities Research Center, the University of Texas at Austin. 
It flings my likeness after the rest and true as any on the shacowcd wilds,

I depart as air .... I slake my white locks at the runaway sun,
I ffiuse my flesh in eddies and drift it in lacy jags.

I bequeath myself to the dirt to grow from the grass I love, If you want me again look for me under four bootsoles.

You will hardly know who I am or what I mean, But $I$ shall be good heal th to you nevertheless,

And filter and fibre your blood.

Failing to fetch me me at first keep encouraged, Missing me one place seareh another,
I stop some where waiting for you
Figure 2. Page 56 of the First Edition
77

Why should I be afraid to trust myself to you?

I am not afraid .... I have been well brought forward by you

I love the rich running day, but I do not dosert her in whom I lay so long :

now not how I came of you, and I know not where I go with you .... but I

I will stop only a time with the sight .... and rise betimes.

I will duly pass the day 0 my mother and duly return to you

vot you will yield forth the dawn again more surely than you will yield forth me again,
Not the womb yiolds the babe in its time more suroly than I shall be yiolded from you in my timc

\section{Leaves of Gras.}

THE bodieg of men and women engirth me, and I engirth them,
They will not let me of nor $\mathbf{I}$ then till $\mathbf{I}$ go with them and respond to them and love them.

Was it dreamed whether those who corrupted their oxn live bodies could concen themselves?
And whether those who defiled the living were as bad as they who defiled the

dead?

The expression of the body of man or woman balks accollt

The exprosion of the body of man or woman balks
The malo is perfoct and that of the female is perfect.

The expression of a wellmade man appears not only in his face, It is in his walk ... the cor
drees does not hide ling

\section{Leaves of Gras.}

\section{COME closer to me, \\ Push close my lovers and take the best I possess,
Yield closer and closer and give me the best you posgess.}

This is unfished businoss with me.... how is it with you?

I was chilled with the coll types and cylinder and wet paper between us

I pass so poorly with paper and typos .... I must pass with the entact of bodies and souls.

I do not thank you for liking me as I am, and liking the touch of me .... I know that it is good for you to do so.

Were all educations practical and ornamental well displayed out of me, what would it amount to?
Were $\mathbf{I}$ as tho head teacher or eharitable proprietor or wise statesman, what would it amount to?
Were $\mathbf{I}$ to you as the boss employing and paying you, would that satisfy you?

The learned and virtuous and benevolent, and the ụsual terms :

A man like me, and never the usual terms

Neither a serrant nor a master am I,

I take no sooner a large price than a small price... I will have my own whocver

I will be even with you, and you shall be even with mo.

If you are a workman or workwoman I stand as nigh as the nighest that works in If you are a workman or workwoman 1 stand as nigh as the nighest that works in
the same shop,
If you bestow gifts on your brother or dearest friend, $\mathbf{I}$ demand as good ns your If you bestow gifts on your brother or dearest friend, $\mathbf{I}$ demand as good ns your
brother or dearest friend,
If your lorer or husband or wife is wclcome by day or night, I must be personally as
welcome;

Figure 3. Page 57 of the First Edition
Lulled and late is the smoke of the Sabbath morning,

It hangs low over the rows of trecs by the fences,
It hangs thin by the sassafras, the wildcherry and the catbrier under thom.

I saw the rich ladies in full dress at the soiree,

Iheard what the run of poets were saying so long,
Heard who sprang in crinson youth from the whito froth and the water-blue.

Bahold a woman!

Behold a woman!
She looks out from her qualier cap .... her fuce is clearer and more beautiful than the aly.

She sits in an armchair under the shadod porch of the farmhouse,

The sun just shines on her old white head,

Her ample gown is of creamhuod linen,
Her grandsons raised the flax, and her granddaughters spun it with the distaff and the wheet

The melodious character of the carth!

The finish beyend which philosophy cannot go and does not wish to go!

YOUNG man came to me with a message from his brother,
Tow should the young man know the whether and when of his brother?

And I stood before the young man face to face, and took his right hand in my left And $\mathbf{I}$ stood before the young man face to face, and took his right hand in my left
hand and his left hand in my right hand,
And $\mathbf{I}$ answered for his brother and for men answered for
sent these signs.

Him all wait for $\ldots$. him all yield up to $\ldots .$. his word is decisive and final,
Him they accept $\ldots$. in him lave $\ldots$. in him perceive themselves as amid light, Him they accept $\ldots .$. in him have $\ldots$ in him porceive themselves as anid light,
Him they immerse, and he immerses them. Beautiful women, the haughticst nations, laws, the landscape, people and animals,

Figure 5. Page 85 of the First Edition 
the poems in the first edition, then, clearly seems to be an arrangement based on spatial concerns rather than on thematic ones.

The twelfth and final signature leaves just the one blank page, 96, at the end of the book. It all fits, but just barely, and only by juggling the poems and abandoning space and titles along the way. This was a book being set eight pages at a time, since Andrew Rome could ill afford to tie up more standing forms or use more of his limited supply of type than that, so a quarto sheet would be printed four pages on each side, then the type distributed and the next quarto sheet prepared.

In 1855, while making his first book, then, Whitman's printing experience allowed him to figure out how to "condense" his work to make it fit the allotted pages, an important consideration for a poor writer paying for the paper himself and depending on his printer-friend's limited generosity in freeing up his job-press to print a friend's poetry. Whitman would have already become a kind of master of that sort of spatial "condensation" as a newspaper compositor and editor, where he knew every day he would have to fit the news to the set number of pages he had to work with: "all the news that's fit to print" was really "as much news as fits in print."

Whitman would have been proofreading these sheets in two stages, four pages up, then four pages down. This is where things get interesting. Gary Schmidgall a couple of years ago found a variant in a line in the 1855 "Song of Myself" when he and his editor were proofreading the 1855 for Schmidgall's St. Martin's edition ofWhitman; with Schmidgall using a New York Public Library copy as proof text and his editor using the Berkeley copy, they discovered Whitman had in fact entirely altered a line, had actually stopped the press at some point and reset the line. ${ }^{4}$ "The night is for you and me and all" becomes "The day and night are for you and me and all." 5 Schmidgall has made an intriguing argument that this may be Whitman's first self-censoring revision, taming his nighttime self by diluting it with a daytime self. My own sense is that the revision may have more to do with Whitman's obsession to balance day and night throughout the book. Recall how vital the cycle of opposites was to Whitman as a central organizing principle of his book: "Great is youth, and equally great is old age .... great are the day and night; / Great is wealth and great is poverty" ( $L G 1855,93)$, he writes at one point in the 1855 edition, and at other points he underscores his association of day and night with the systole and diastole of life and death, openness and secrecy, transparency and disguise. "Stop this day and night with me and you shall possess the origin of all poems," he writes (14); "I hear all sounds as they are tuned to their uses .... sounds of the day and night" (31). On and on throughout his notes and throughout the first edition, he insists on saying both day and night, and that insistence was great enough to cause him to make his first major alteration in the printed 
Leaves of Grass. As he says in his preface to the 1855 edition, "The United States themselves are essentially the greatest poem. [. . . Here at last is something in the doings of man that corresponds with the broadcast doings of the day and night. [. . .] The American bards shall be [. . .] hungry for equals night and day" (iii, vii). Or maybe his revision of the line is just another example of Whitman's printer's "anticipatory eye," 6 an indentation of a short line between two long ones that Whitman just didn't like the looks of, so he extended it. Whatever the case, something about the change was crucial for Whitman, important enough for him to change this line while the book was actually being printed, and it is the first substantive change Whitman made to Leaves of Grass. It is the first of thousands of such changes he would make to the book over the next twenty-six years, and it went unnoticed for nearly 150 years.

The census shows that the earlier "night" version of the line appears in nearly thirty percent of the copies (44 of 158) that our census has so far identified. This means that, since the kind of letterpress Rome used would probably have been able to print 800 copies of one side of a quarto sheet in a couple of hours, Whitman had to stop the press fairly quickly, after say 45 minutes, to pull off the form and reset the line of type. Something very important must have seemed wrong (yet not so important that Whitman could afford to trash the now-flawed sheets that had already been printed). Whatever it was, it was clearly enough to occupy Whitman's attention as he was reading proof of one of the first of the sheets to be printed.

I have reconstructed that quarto sheet so we can see what it would have looked like (see Figure 6). Amy Hezel and I spent a lot of time last year folding probably a ream of paper into quarto sheets to keep reminding ourselves what Whitman would have been seeing when those sheets came off Andrew Rome's press. In Figure 6 you can see, strikingly, that page 49 , with the "night" line, appeared right next to page 56 , the final page of "I celebrate myself," and the page with the most notorious typographical error in the book. Or two errors. One is a real error, an embarrassing double "me" in the final triplicate of the poem, an obvious mistake that Whitman did not catch: "Failing to fetch me me at first keep encouraged." In those minutes he spent proofing, something about that "night" line so preoccupied him that he was already rewriting it, thinking about setting it in type, and not going over the other pages as carefully as usual. At first, this seemed to explain how Whitman could have missed the double "me" and also how he could have overlooked the now-famous missing period at the end of the poem. But one thing the census has revealed is that when Whitman first looked at this page, a period was in fact there. It appears in seven remaining copies, but after about five percent of the press run, the period began slipping and jammed into the "u" at the end of the final word of the poem. Several 


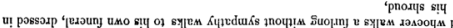

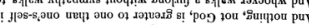

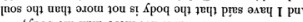

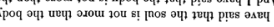

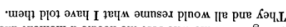

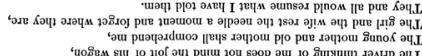

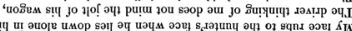

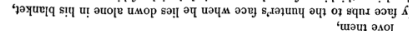

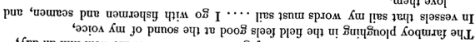

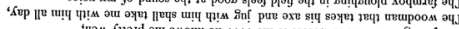
‘f

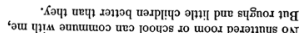

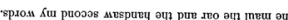

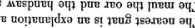

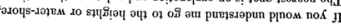

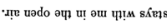

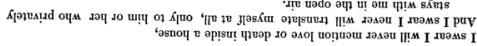

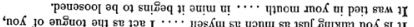

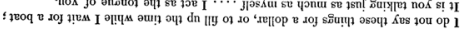

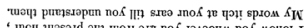

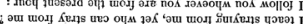

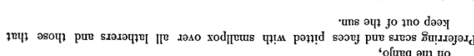

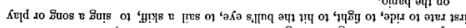

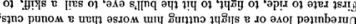

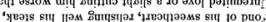

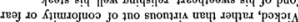

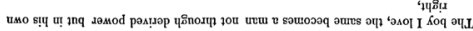
$\varepsilon$ -ssudg yo son

It flings my likeness after the rest and true as any on the shadowed wilds, It coaxes me to the vapor and the dusk.

I depart as air .... I shake my white locks at the runaway sun, I effuse my flesh in eddies and drift it in lacy jags,

I bequeath myself to the dirt to grow from the grass $\mathrm{I}$ lore If you want me again look for me under your bootsoles.

You will hardly know who $\mathbf{I}$ am or what I mean, But I shall be good health to you and fibre your blood.

Failing to fetch me me at first keep encouraged, Missing me one place search anothe,

I stop some where waiting for you.

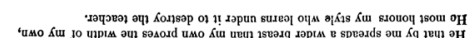
政

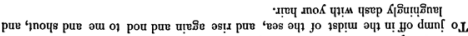

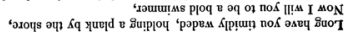

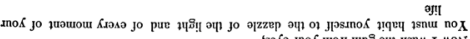

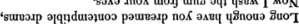

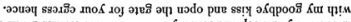

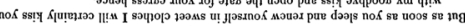

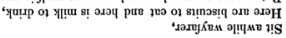

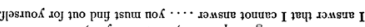

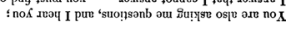

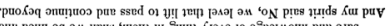

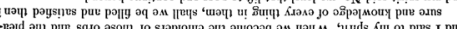

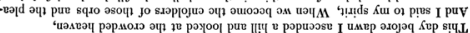

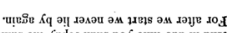

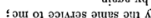

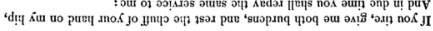

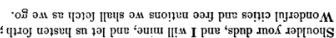

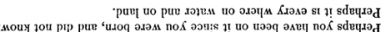

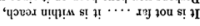

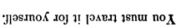

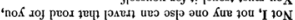

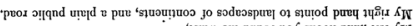

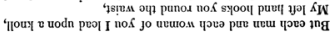

's

The past is the push of you and me and all presiscly thic satne, and me and all, And what is yet untried and afterward is for you and me and al.

I do not know what is untried and afterward, But I know it

Each who passes is considered, and each who stops is considered, and not a single one can it fail.

It cannot fail the young man who died and was buried,

Nor the young woman who died and was put by his side,
Nor the littlo child that peeped in at the door and then drew back and was never scen again,
ar the old wan who has lived without purpose, and feels it with bitterness worso

than gall,

Nor him in the poorhouse tubercled by rum and the bad disorder,

Nor him in the poorbouse tubercled by rum and the bad disorder,
Numberless slaughtered and wrecked .... nor the brutish koboo, called tho ordure of humanity,

Nor tho sacs merely floating with open mouths for food to slip in,

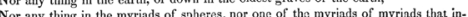
habit them,

It is time to erplain myself .... let us stand up.

What is known I strip away .... I launch all men and women forward with mo into the unknown.

The clock indicates the moment .... but what does eternity indicate?

Eternity lies in bottomless reservoirs .... its buckets are rising forever and evcr, They pour and they pour and they exhale away.

Wo have thus far exhausted trillions of winters and summers;

There are trillions ahead, and trillions ahead of them.

Births have brought us richness and variety,

And other births will bring us richncss and variety.

I do not call one greater and one smaller,

That which fills its period and place is equal to any.

Were mankind murderous or jealous upon you my brother or my sister?

Figure 6. Reconstruction of the Quarto Sheet of Pages 52, 53, 56, and 49. 
copies show that collision, before the period breaks off the descender of the "u" and eventually falls off.

Years ago, Arthur Golden tried to lay to rest the myth that Whitman intended to leave off the period by pointing out that in 1856 he quickly put the period back on, and by pointing out that no one has tried to make an argument that there's special meaning in the missing period at the end of another line earlier in the poem that everyone has simply read as a typo. ${ }^{7}$ Type on the Rome press was doing a lot of slipping, especially in short lines where the end leading was not always tightly or carefully completed. So, when Whitman's eyes swept over that final page of "I celebrate myself," he would have seen the period at the end, even as he missed the double-me in his preoccupation with the line on the adjoining page that was already bothering him enough that he was thinking of resetting it.

Over the past century, entire readings of Whitman's "Song of Myself" have been predicated on that missing period. Just last year, in a newspaper column for the sesquicentennial, Michael Ventura ends his analysis with this: "I stop somewhere waiting for you - that is the last line of his poem, and he placed no period at the end of that sentence. It's an open-ended proposition. ... Without a period, the poem never ends. We're expected to fulfill it." Or, to take a more scholarly example, Andrew Lawson in his new book Walt Whitman and the Class Struggle ends his analysis of the poem by quoting the final lines without the period and noting, "Whitman cannot bear to end his song - now contending, now mingling - with so much as a full stop." It's a nice idea, but it has one flaw: the missing period is in fact a printing accident. ${ }^{8}$

Before Schmidgall's discovery of the change in the "day and night" line, numerous variations between copies of the 1855 Leaves had been noted, most of them having to do with loose type or poor inking. There was one typographical error in the preface — an "adn" for "and" - that Whitman at some point corrected, but what hasn't been known is whether or not copies containing this typo are common or rare. Our preliminary census results indicate there are in fact very few copies with the typo (only fifteen)-Whitman made that correction very early in the print run. While the copies with the uncorrected "adn" are almost all in the first-state bindings, as we would expect (since the "adn" sheets were the earliest printed), not all of them are (two second-state copies have the "adn"). And, even more surprisingly, about an equal number of copies with the earlier version of the "night" line appear in the second-state bindings of the book and in the first-state bindings, and this tells us a lot about how Whitman or someone mixed up the signatures when they went to the binder. This discovery, of course, opens the possibility that other revisions like this one may appear, since, if Whitman stopped the press on several different occasions early on in the press run of various 
sheets, additional variations may well have escaped notice, just as this one did for a century and a half.

And it gets even more complicated. Our census so far shows that all but one of the copies with the uncorrected "adn" have the corrected version of the "day and night" line. That is to say, the uncorrected first signatures with the preface were almost always collated with the corrected later signature with that section of "Song of Myself." Apparently the stacks of signatures were not systematically stacked in Rome's cramped shop, and, as the sheets got carried (by wheelbarrow, by wagon, by horse and carriage?) from Rome's shop to Jenkins's bindery, no one seems to have worried about keeping the signatures in uniform order, so signatures from early in the press run were bound with signatures from late in the press run, and, since the errors tended to be corrected early in the press run (Whitman must have been madly proofreading the first sheet off the press as Andrew Rome, squeezing this bookmaking job in between his real work, kept printing the sheets), the pages with errors do not all appear in the same copies of the book; they are in fact distributed very nearly randomly among the copies - one error may appear in the same copy with another correction.

We can begin multiplying the resultant possible variations. The book was printed as a quarto, so eight pages of type would have been set at once, and four pages printed simultaneously, with pages $1,4,5$, and 8 on one side of the sheet; then the sheet would have been turned over and pages 2, 3,6, and 7 printed on the other side. The eight-page signatures form a unit; there were twelve of these units in the 96-page book. If, as it appears, there are several states of each signature (and also, within the signatures, variations occur, since the four pages printed on one side of the quarto sheet were a different press run than the four pages on the other side: that is, Whitman would have been proofreading and making corrections on only four of the eight pages at a time), and if the twelve eight-page signatures are combined in various ways, the intriguing possibility arises that every copy of the first edition may be unique. Add to this Ted Genoway's discovery about the changes in the frontispiece engraving, where, to save money, Whitman apparently used the earlier versions of the engraving in the second state bindings, while the later version of the engraving is in all first state and some second state bindings; and add to this the binding variations: just how many versions of the 1855 edition are there? A particular copy might have a second-state cover, a thirdstate engraving, a first state of the first signature but a fifth state of the second signature, a fourth state of the third, and so on. For all we know at this point, there may be 795 variations.

I should mention a bit more about Genoways's discovery concerning the frontispiece engraving. ${ }^{10}$ Facing the title page, Whitman included an engraving of a daguerreotype of himself, a full-body portrait, with 
working clothes and hat on. This is a poetry, the portrait seemed to say, that comes from the body as much as from the mind, that emerges from the working classes instead of from the privileged, educated aristocrats. Genoways has recently discovered some intriguing variations in the frontispiece engraving, suggesting that Whitman may have worked with the engraver to enhance the bulge of the crotch in the figure, thus giving visual support for Whitman's introduction of his name halfway through "I celebrate myself": "I [. . . ] make short account of neuters and geldings, and favor men and women fully equipped, / And beat the gong of revolt, and stop with fugitives and them that plot and conspire. / Walt Whitman, an American, one of the roughs, a kosmos, / Disorderly fleshy and sensual .... eating drinking and breeding" (29). The bulging-crotch version of the engraving appears in all of the copies in the first binding, but many of the copies in the second binding contain the earlier flatcrotch image, again demonstrating that Whitman always saw his books as works in progress; he was economical enough not to throw out the things already printed, but he was never bound to what he thought could be made more effective: he just made the changes and left the old copies behind him, like a trail of evolutionary debris, a record of the evolution of Leaves of Grass.

Because he did not have much money, Whitman had copies of the 1855 edition bound on at least four different occasions from June 1855 to January 1856, producing another group of books whenever he had the cash, and he was forced to use increasingly cheaper bindings and finishing methods, ending up with a small run of paperbound copies. In the census, there are 86 copies in the first-state binding (green morocco with gilded edges on the pages and gilding on front and back covers), 59 in the second state (green morocco with no gilded edges, gilding on only the front cover), four in the paper or "board" covers, and eight rebound. Most bibliographies of Whitman recognize only three "states" of the first edition, based on the differences in the cover. But Whitman contracted the binding work out to the Brooklyn firm of Charles Jenkins, whose invoice to Whitman indicates he bound 200 copies in June of 1855, all in the first-state binding. Jenkins then subcontracted the work to another firm, Davies \& Hands, who, according to the invoice, bound another 137 copies in the first-state binding in July 1855, along with 46 copies in "boards." Then in December, Davies \& Hands bound 169 in the second-state binding, and in January of 1856 bound 150 in paper and 93 more in the second-state cloth. ${ }^{11}$ That makes a total of 795 copies: 337 first-state bindings (42 percent); 262 second-state bindings (33 percent); 46 bound in "boards," meaning cardboard (six percent); and 150 in paper covers (19 percent). The census of extant copies breaks down as follows: first-state bindings, 54 percent; second-state bindings, 37 percent; paper, board, and rebound copies, eight percent. We counted 
rebound copies as originally having paper and board covers because our assumption is that most owners would have repaired the distinctive cloth bindings instead of having them rebound, while owners of the paperbound and boardbound copies, which deteriorated quickly (only four known copies still in paper or board covers survive), might well have needed to be rebound. The cheapest and most ephemeral bindings over time, of course, become the most rare.

One complication here is that no one has attempted to distinguish between the first-state bindings done by Jenkins and the first-state bindings done by Davies \& Hands. Book conservationists looking at several first-state covers have indicated to me that it appears that there are some discernible differences among the covers, and so it may be possible, upon further examination, to distinguish between the books bound by Jenkins and those bound by Davies \& Hands, in which case there will be at least one additional "state" of the binding. It may also be possible to distinguish between the first batch of second-state bindings done by Davies \& Hands and the second batch done a month later. Given this breakdown - a "first-state" binding done by Jenkins, a "first-state" binding done by Davies \& Hands, two "second-state" bindings done by Davies \& Hands, a board binding by Davies \& Hands, and a paper binding by Davies \& Hands - we may be able eventually to identify six states of the binding.

When Leaves first appeared, Whitman's book as a physical object was certainly perceived as unusual in size, ornamentation, and design. One early reviewer in Life Illustrated commented on its "curious title" and went on to say that "the book itself is a hundred times more curious. It is like no other book that ever was written." This reviewer described the book object as "shaped like a small atlas." Edward Everett Hale in North American Review threw up his hands at trying to describe it: "Everything about the external arrangement of this book [is] odd and out of the way." 12

Almost all the reviewers commented on the absence of the author's name and the odd frontispiece engraving - "the unique effigies of the anonymous author," "the picture of a perfect loafer." The reviewer for the Critic found similar qualities in the author and the book: "The man is the true impersonation of his book - rough, uncouth, vulgar." The popular author Fanny Fern even seems to have noticed the extra bulge in the crotch; in her review of the first edition she talks of how "sensual" the book is and comments: "Sensual? The artist who would inflame, paints you not nude Nature, but stealing Virtue's veil, with artful artlessness now conceals, now exposes, [his] ripe and swelling proportions." Charles Eliot Norton, in his Putnam's Monthly review, summed up the feeling of many when he described it as "this gross yet elevated, this superficial yet profound, this preposterous yet somehow fascinating book." Only in 
recent months, as we've come back to the physical book with fresh eyes, as we've begun to really think of Whitman as a bookmaker, as an artist as interested in his book objects as in his texts, have we come to see just how profound the superficialities are, just how elevated the gross can be, just how fascinating this preposterous printer-poet truly is. ${ }^{13}$

\section{The University of Iowa}

The complete census form and the current results-in a searchable database - are available at the WWQR website: www. uiowa.edu/ wwqr. Also available at the website is Amy Hezel's essay summarizing the results.

\section{NOTES}

1 Gay Wilson Allen, "Regarding the 'Publication' of the First Leaves of Grass," American Literature 28 (March 1956), 79.

2 Whitman, The Correspondence, ed. Edwin Haviland Miller (New York: New York University Press, 1977), 30.

3 John Lockwood, Poems of Earlier Years (Brooklyn: Rome Brothers, 1871).

4 Gary Schmidgall, “1855: A Stop-Press Revision,” Walt Whitman Quarterly Review 18 (Summer/Fall 2000), 74-76.

5 Leaves of Grass (Brooklyn, New York: 1855), 49. The shorter line is the earlier one, since the longer version is much closer to the line that then appears in the 1856 and 1860 editions ("Day and night are for you, me, all"); Whitman dropped the line after the 1860 edition. The first edition (along with all the other editions) is available online at the Walt Whitman Archive (www.whitmanarchive.org).

6 Horace Traubel, With Walt Whitman in Camden (various publishers, 1906-1996), 5:390.

7 The line is on page 52: "You must habit yourself to the dazzle of the light and of every moment of your life"; this line is the third line in a triplicate set and is without a period in all copies. See Arthur Golden, "The Ending of the 1855 Version of 'Song of Myself," Walt Whitman Quarterly Review 3 (Spring 1986), 27-30.

8 See Michael Ventura, "Look for me under your boot-soles," Austin Chronicle (July 22, 2005), 28; and Andrew Lawson, Walt Whitman and the Class Struggle (Iowa City: University of Iowa Press, 2006), 99.

9 Leaves 1855, iv. This error and its correction are first noted in Michael Winship, ed., Bibliography of American Literature (New Haven:Yale University Press, 1991), 9:31.

10 Ted Genoways explores the changing frontispiece in "'One Goodshaped and Wellhung Man': Accentuated Sexuality and the Uncertain Authorship of the Frontispiece 
to the 1855 Edition of Leaves of Grass," in Susan Belasco, Ed Folsom, and Kenneth M. Price, eds., Leaves of Grass:The Sesquicentennial Essays (Lincoln: University of Nebraska Press, forthcoming).

11 See William White, “The First (1855) Leaves of Grass: How Many Copies?," Papers of the Bibliographical Society of America, $3^{\text {rd }}$ quarter (1963), 352-354. There are still mysteries here; in the "George Walker" notebook, for example, Whitman records "70 in paper / 5 in cloth \& gilt" near the date "Nov. 23." It is possible that Davies \& Hands bound some of the paper copies of the 1855 edition in November 1855 and simply listed all 150 under January 1856 on the invoice. See Whitman, Notebooks and Unpublished Prose Manuscripts, ed. Edward F. Grier (New York: New York University Press, 1984), 238.

12 Kenneth M. Price, ed., Walt Whitman:The Contemporary Reviews (New York: Cambridge University Press, 1996), 8, 34.

13 Price, 3, 43, 47, 15. 